\title{
SOME PROBLEMS WITH THE UNIFORM TRUSTEES' POWERS ACT
}

\author{
PaUl G. HaskelL*
}

\section{INTRODUCTION}

The modern trust is an instrument of considerable utility for the donor who wishes to retain control while giving. It offers the potential of skilled management, investment flexibility, preservation of value, administrative economy, and tax minimization, through time and changing circumstances, for the benefit of successive beneficiaries. The modern trust is a sophisticated property management device the efficiency of which has been somewhat impaired by the inheritance of restrictive principles that are not suited to its contemporary needs and purposes. ${ }^{1}$ In most jurisdictions there is legislation liberalizing trustees' powers in varying degrees, but frequently the legislation is an unsatisfactory patchwork. ${ }^{2}$ Previous uniform legislation dealing with trustees' powers ${ }^{3}$ has been limited in scope. The proposed Uniform Trustees' Powers Act (hereinafter referred to as the "Act") ${ }^{4}$ does a great deal to bring the law of fiduciary administration into line with current needs by substantially expanding and making flexible the powers of trustees beyond their traditional limits.

In certain respects, however, the Act seems to provide greater scope to fiduciary action than is necessary for the efficient performance of the trust function. Obviously the expansion of the trustee's freedom in the interest of sound management is in the best interest of the beneficiaries, but some of the liberalizing provisions of the Act seem to serve primarily the purpose of fiduciary exculpation or advantage, particularly with respect to the bank fiduciary-or at least so it appears to this writer. The purpose of this article is to evaluate the Act generally, with some emphasis at appropriate points upon the manner in which it appears to afford advantages to the corporate fiduciary at the expense of other values or interests.

- A.B. I948, LL.B. I95I, Harvard University. Professor of Law, Case Western Reserve University School of Law.

${ }^{1}$ Fratcher, Trustees' Powvers Legislation, 37 N.Y.U.L. Rev. 627 (1962); see 2 A. Scorr, Law or Trusts $\$ 186$ (2d ed. I956).

${ }^{2}$ Fratcher, supra note 1 , at 628-29.

${ }^{3}$ Uniform Common Trust Fund Act; Uniform Fiduciaries Act; Uniform Principal and Incomb ACt (I93I); UNIForM PRINCIPAl AND INCOME ACT (Revised I962); UNIForM Simplification of Fiduciary Security Transfers Act; Uniform 'Trustees' Accounting Act; Uniform 'Trusts Act.

'The Uniform Trustees' Powers Act is set forth in its entirety in the appendix to this article. It was adopted by the National Conference of Commissioners on Uniform State Laws in 1964. It was enacted in Idaho and Wyoming in 1965, and by Mississippi in 1966. IDArto Code ANN. \$\$ 68-104 to -113 (Supp. 1965); Wro. Stat. ANN. $\$ \$ 4-36$ to -45 (Supp. 1965); Miss. Code ANN. $\$ \$ 672-121$ to -133 (Supp. 1966). Charles Horowitz, the chairman of the committee that drafted the Act, has written an explanatory article, Uniform Trustees' Posvers Act, $4 \mathrm{I}$ Wash. L. Rev. I (I966), and Professor Robert W. Hallgring has written a critique of the Act, The Uniform Trustees' Powers Act and the Basic Principles of Fiduciary Responsibility, 4I Wasr. L. REv. 80r (Ig66). 
The text of the Act is printed as an appendix to the article for ease of reference. It should be noted at this point that the Act applies only to the conventional express private trust and charitable trust, and is not applicable to commercial trusts such as the pension or other employee benefit trust or the investment trust. ${ }^{5}$

I

\section{BACKGROUND}

At the outset it should be mentioned that there is a certain air of unreality about any controversy over trustees' powers, in view of the fact that the matter is almost wholly within the control of the draftsman of the trust instrument. In a sense, the innovations of the Act do not present a novel issue, since, for the most part, the same provisions could effectively be included in any trust instrument. The body of law that has developed to restrict the actions of the trustee is operative in the absence of the grant of power by the settlor. Trust terms prepared by lawyers who are experts in the field of trust law frequently contain a grant of powers that is not dissimilar in substance from many of the provisions of the Act. So it seems that the breadth of fiduciary power provided by this legislation has been, in substantial measure, part of trust law right along, in the sense that such terms have been enforceable where expressed in the trust instrument; broad fiduciary powers, including self-dealing and delegation of discretionary decision-making, have not been generally considered contrary to public policy where that is what the settlor wanted.

What is proposed by the Act is that express negation in the trust instrument be required if certain broad powers are not to exist, ${ }^{6}$ rather than that the grant of broad powers be contained in the instrument if they are to exist. It may well be said that the law as it presently stands, to the extent that it is restrictive of fiduciary power where freedom of fiduciary action is desirable, or to the extent that the existence or nonexistence of such power is in doubt, only serves to penalize those whose counsel did not anticipate the particular power that subsequently seemed to be called for. The impact of the Act upon fiduciary administration may not be as great as appears at first blush.

The common law position has been that the trustee has only such powers as are granted to him, expressly or impliedly, by the trust instrument; in theory, the trustee is said to have no powers solely by virtue of his office. The implied power is one which is necessary or appropriate for the carrying out of the purposes of the trust, although not expressly granted. For example, if there is no provision in the trust instrument expressly empowering the trustee to sell assets originally transferred in trust, then the trustee does not have the power unless it appears from the nature

\footnotetext{
¿ $\mathrm{I}(\mathrm{I})$ of the Act.

- "The trustee has all powers conferred upon him by the provisions of this Act unless limited in the trust instrument ...." $\$ 2(a)$ of the Act.

${ }^{7}$ Restatement (Second) of Trusts $\$ 186$ (1959); Fratcher, supra note I, at 627 .
} 
of the property transferred, or the purpose of the trust, or language in the trust instrument, such as that which speaks of "investing and reinvesting" trust assets, that the power of sale is implied, as it usually is. ${ }^{8}$ The implied power is considered to be reflective of settlor intention, however fictitious the application of the volitional principle sometimes may be. The necessity to find an express grant of power or an implied grant of power presumably has its origins in the feudal use, which came into. being for the purpose of avoiding certain feudal obligations or achieving certain feudal goals otherwise unattainable and in which the holder of legal title had few, if any, duties to perform; the feudal holder of legal title to the use of another was usually something of a straw man. ${ }^{9}$ In the post-feudal, post-Statute of Uses period, frequently the trustee's functions were strictly limited; the trust was often employed only as a device for maintaining the continuity of land ownership in the family line. ${ }^{10}$ The trustee formerly was not viewed as an investment specialist as he often is today.

It is obvious that a sophisticated court can find that the trustee has an "implied" power if it makes sense for him to have it, so long as there is no express prohibition in the trust instrument. There has been, however, much litigation concerning the existence or nonexistence of trustee power where a good case could be made that sound management called for the existence of the power; the idea that a power must be "found" in the trust instrument at best breeds litigation and at worst obstructs proper trust administration. ${ }^{11}$ It should be stressed that legislation has been enacted in most jurisdictions granting various specific powers to trustees which serve to supplement the common law criteria for the determination of trustee powers. ${ }^{12}$

\footnotetext{
${ }^{8}$ Church v. Church, 40 Cal. App. 2d 696, ro5 P.2d 640 (1940); Sword v. Marquette Nat'l Bank, 252 Minn. 544, 9 I N.W.2d 75 (I958); Agisim v. Tillou Realty Co., 56 N.J. Super. I8, I5I A.2d 42I (Ch. 1959); Will of Walker, 258 Wis. 65, 45 N.W.2d 94 (1950); 2 A. Scort, supra note I, \$\$ 186, 190, 190.I, $.2,3$.

${ }^{-}$See T. F. Bergin \& P. G. Haskell, Preface to Estates in Land and Future Interests 84-120 (1966).

${ }^{10}$ Fratcher, supra note $I$, at 658 .

${ }^{12}$ See, e.g., Hartford Nat'l Bank \& Trust Co. v. Parish of Trinity Church, 25 Conn. Supp. 23, 195 A.2d 566 (Super. Ct. I963) (power of trustee to make improvements on realty); Adler v. Adler, 216 Ga. 553, II8 S.E.2d 456 (196I) (power of trustee to give an option to purchase trust property); Montgomery Ward \& Co. v. Norton's Trustee, 255 Ky. 244, 73 S.W.2d 4 I (I934) (power of trustec to give a lease extending beyond period of trust); Estate of Dickerson v. Dickerson, 24 N.J. 513, I32 A.2d 805 (1957) (power of trustee to borrow money); King v. Pelkofski, 24 App. Div. 2d I003, 266 N.Y.S.2d 6r, appeal dismissed, I 8 N.Y.2d 688, 219 N.E.2d 884 (1965) (power of trustce to mortgage); In re Estate of Gould, 17 App. Div. 2d 40r, 234 N.Y.S.2d 825 (1962) (power of trustee to sell on credit).

${ }^{12}$ E.g., the power to sell-LA. Rev. Stat. $\$ 9: 1998$ (1950); Mass. Gen. Laws ANN. ch. 203, $\S 9$ (1955); N.Y. DECED. EsT. LAW $\$ 127$ (2)(f) (McKinney Supp. 1966); the power to grant options-FLA. Stat. ANN. \$69x.03(2) (I944); Ill. ANn. Stat. ch. I48, §35(A)(I) (Smith-Hurd I964); N.Y. Deced. Est. Law $\$ 127$ (2)(i) (McKinney Supp. I966); the power to sell on credit-R.I. GEN. Laws ANN. $\$ 18-4-2$ (b) (Supp. r966); Tex. Rev. Civ. Stat. ANn. art. 7425b-25(B) (I960); Wash. Rev. CodB $\$ 30.99 .070$ (I959); the power to mortgage-FLA. Stat. ANN. \$691.03(16) (1944); PA. STAT. ANN. tit. $20, \$ 320.964$ (Supp. 1966); the power to lease beyond term of trust-CaL. Civ. Code $\$ 2272$ (West I954); N.Y. DECED. EsT. LAW $\$ 127(2)(f)$ (McKinney Supp. 1966); majority of trustecs can excrcise powers-Nev. Rev. Stat. \$ I63-ryo (rg6r); N.M. Stat. ANn. \$33-3-1I (I953); N.C. Gen. Stat.
} 
It should also be noted that the doctrine of administrative deviation or augmentation obtains at common law, by which the court authorizes the trustee to act where there is no express or implied power; this requires that there be circumstances sufficiently compelling to warrant a judicial alteration of the terms of the trust. This principle may be employed to authorize trustee action which has been expressly prohibited by the terms of the trust, as well as to authorize trustee action in the absence of express or implied power or any express prohibiton upon such action. The doctrine of administrative deviation or augmentation is considered to be applicable only in exceptional circumstances where strict adherence to the terms of the trust would endanger the purposes for which the trust was created..$^{\mathbf{1 3}}$

\section{"Prudent MaN" Powers}

The Act takes a significant step by empowering the trustee to do all things in the management of the trust that a man of ordinary prudence and judgment would do, subject at all times to his obligation as a fiduciary, ${ }^{14}$ thereby going beyond the traditional formula of the grant of power, express or implied, from the settlor. This broad provision seems to empower the trustee to do what it is reasonable for him to do in the management of the assets in trust, without the restrictions founded in history and without resort to the frequently fictitious implied authority founded upon settlor intention.

The "prudent man" concept seems to have been taken from the doctrine of that name which obtains in many jurisdictions with respect to the standard applied to the trustee in his investment function..$^{15}$ That is to say, given the power in the trustee to invest trust assets, under the flexible prudent man investment standard the trustee is not rigidly limited to certain prescribed types of investments but rather is empowered to invest as a man of prudence and judgment would. ${ }^{16}$ The prudent man standard

$\$ 36-34$ (1966); the power of corporate trustee to retain own stock-statutes cited note 23 infra; the power of corporate trustee to deposit in own banking department-statutes cited note 24 infra; the power of corporate trustee to hold securities in name of nominee-statutes cited note 33 infra.

Several states presently have relatively broad trustees' powers legislation. E.g., Fla. Stat. ANN. ch. 69I (1944, Supp. 1966); PA. Stat. ANn. tit. 20, $\$ 320.931-.969$ (1950, Supp. 1966); WAsh. Rev. CODE $\$ \$ 30.99 .0$ ro-.910 (r959).

See generally Fratcher, supra note I, for a compendium of legislation dealing with trustees' powers.

${ }^{13}$ Stanton v. Wells Fargo Bank \& Union Trust Co., I50 Cal. App. 2d 763, 3ro P.2d roro (x957); Colonial Trust Co. v. Brown, I05 Conn. 26I, I35 A. 555 (I926); Carlick v. Keiler, 375 S.W.2d 397 (Ky. 1964); In re Trusteeship Under Agreement with Mayo, 259 Minn. 9I, I05 N.W.2d 900 (I960); In re Estate of Pulitzer, 139 Misc. 575, 249 N.Y.S. 87 (Sur. Ct. 193X), aff'd mem., 237 App. Div. 808, 260 N.Y.S. 975 (I932); Restatement (SECOND) of Trusts $\$ 167$ (I959).

It $\$ \S \mathrm{Y}(3), 3(\mathrm{a}), 3$ (b) of the Act.

${ }^{10}$ Sec Handiook of the National Conference of Commissioners on Uniform State Laws 265 $(x 964)$.

10 The prudent man standard in the investment function was recognized in the leading case of Harvard College v. Amory, 26 Mass. (9 Pick.) 446 ( 1830 ). This investment standard is also supported by Restatedent (SEcond) of Trusts $\$ 227$ (1959). The powers of trustee investment are now generally the subject of legislation, and many jurisdictions have legislated the prudent man standard. E.g., KaN. 
has also been employed with respect to the trustee's general duty of care and skill in the management of the trust estate. ${ }^{\mathbf{1 7}}$

It should be noted that the Act provides that the conduct of the trustee under the prudent man standard is analogous to the conduct of the prudent man in the management of his own property. ${ }^{18}$ But the Act apparently also provides that the trustee under this standard is required to think beyond the present income needs in his management, and is required to act as well to preserve the value of the principal for subsequent beneficiaries; this seems to require possibly greater conservatism than would be required merely for the protection of the prudent man's own interest. ${ }^{10}$ It should also be noted that the Act specifically provides that investment powers generally are not affected by its provisions; the existing law as to trustee investment, whether the prudent man standard or the legal list or some mix of these categories, continues in effect. ${ }^{20}$

For the purpose of determining the extent of the general duty of care that is required of a trustee, any special skills possessed by a trustee, and representations by a trustee as to special skills possessed by him, have been considered to be relevant; ${ }^{21}$ that is to say, the trustee may be held to a standard of care higher than the external standard of reasonable care and skill which a man of ordinary prudence would employ in the management of his own property, if he possesses such superior skill or represents that he does.

Although the Act deals with "powers" rather than "duties," nevertheless these concepts necessarily are very much interrelated. Obviously the trustee cannot be empowered to do that which his duty of care prohibits; if the duty of care requires more of the trustee than the external standard of prudence, then his powers must also be so qualified. In view of this, it is unfortunate that the Act does not recognize the applicability of these higher standards when appropriate; the absence of provisions to this effect would seem to be protective of the trustee, particularly the bank trustee, at the expense of sound fiduciary administraion. It is recognized that the corporate fiduciary frequently possesses special skills, or at least represents itself in

Gen. Stat. AnN. $\$$ I7-5004 (Supp. I965); ME. Rev. Stat. ANn. tit. 18, §4054 (1964); N.H. Rev. Stat. ANN. $\$ 564: 18$ (1955, Supp. I965); OkLA. Stat. ANN. tit. 60, $\$$ I6r (1963); Ore. Rev. Stat. $\$ 128.020$ (I965); Tenn. CODE ANn. \$35-320 (I955); Wash. Rev. CODE $\$ 30.24 .020$ (I955).

${ }_{17}$ Restatement (SECOND) OF Trusts $\$ 174$ (I959); 2 A. ScotT, supra note $1, \$ 174$.

${ }^{18} \S \mathrm{I}(3)$ of the Act.

10 The language of $\S \mathrm{I}(3)$ of the Act is somewhat confusing-the action of the trustee must be reasonable and equitable "in view of the interests of income or principal beneficiaries, or both."

${ }^{20} \$_{3}(\mathrm{c})(5)$ of the Act.

${ }^{21}$ Liberty Title \& Trust Co. v. Plews, I42 N.J. Eq. 493, 60 A.2d 630 (Ch. 1948), affd, 6 N.J. Supcr. I96, 7o A.2d 784 (App. Div. 1950), affd, 6 N.J. 28, 77 A.2d 219 (1950); Will of Church, 22r Wis. 472, 266 N.W. 210 (1936); G. Bogert, Trusts and Trustees $\$ 54 \mathrm{I}$ (2d ed. 1960); 2 A. ScotT, supra note $I, \$ I_{74}$, I74.I. It probably remains conventional trust doctrine, however, that trustees are to be held to the standard of prudence and judgment of the ordinary man, regardless of the special compctence possessed or represented. See Security Trust Co. v. Appleton, 303 Ky. 328, I97 S.W.2d 70 (1946); Linnard's Estate, 299 Pa. 32, 148 A. 912 (1930); Note, Standard of Care for Corporate and Professional Trustees, 42 VA. L. REv. 665 (1956). 
advertising or otherwise as possessing such skills. The failure to include specifically in the Act these higher standards of prudence and judgment with respect to trustees' powers seems to be without justification. But, in addition, the failure so to provide results in a significant logical contradiction if the principles with respect to a more stringent fiduciary duty of care are accepted. It would be most unfortunate if the Act were to have the effect of limiting the development in trust law of the salutary higher standard of care for those trustees that are specially skilled or purport to be so.

\section{III}

\section{Fiduciary Self-Dealing and Delegation}

The Act empowers the trustee to do all acts that an ordinarily prudent man would do in the Administration of the trust, subject to his obligation as a fiduciary. This fiduciary obligation presumably requires the trustee to act in a selfless manner in the interests exclusively of the beneficiaries and impartially with regard to the several beneficiaries, although the fiduciary obligation is not defined in the Act. The Act also sets forth a number of specific powers that the trustee is to have, which enumeration does not limit the generality of the "prudent man" powers which he has. ${ }^{22}$ Included among the enumerated powers are several allowing forms of selfdealing and delegation of authority which are somewhat controversial.

\section{A. Self-Dealing}

Section $5(\mathrm{~b})$ of the Act provides that the trustee may engage in self-dealing transactions only with the authorization of the court, except that the self-dealing specifically authorized in several enumerated subsections of the Act does not require such judicial authorization. The Act does not make any change in the law with respect to the sanctions applicable to unauthorized self-dealing.

\section{Retention of Assets in Which the Trustee Has an Interest}

Section 3 (c) (I) of the Act provides that the trustee is empowered to retain assets received in trust from the settlor in which the trustee has a personal interest; this form of self-dealing does not require any judicial approval. At common law retention of such an asset would be lawful only if expressly authorized by the settlor or if the retention would be necessary or appropriate for the carrying out of the purposes of the trust. ${ }^{23}$ The Act permits retention irrespective of express or implied authorization. Needless to say, under the Act retention is only permissible if the asset is other-

\footnotetext{
${ }^{22}$ Sce $\$ \S_{3}(\mathrm{a})$, (c) of the Act.

${ }^{23}$ In re Estate of Ridings, 297 N.Y. 4 I7, 79 N.E.2d 735 (I948); In re Durston, 297 N.Y. 64, 74 N.E.2d 310 (1947); In re Trusteeship of Stone, 138 Ohio St. 293, 34 N.E.2d 755 (194I); Child Estate, I5 Pa. D. \& C.2d 257 (Orphans' Ct. 1957). Some states have legislated that the corporate trustee may retain its own shares acquired from the settlor. GA. Code ANN. $\$$ I13-1518 (Supp. 1966); Ky. REv. STAT. $\$ 386.025$ (I962); Mo. Ann. Stat. $\$ 363.200$ (I952); Tex. Rev. Civ. Stat. AnN. art. 7425b-I4 (Supp. 1966). See also 12 C.F.R. $\$ 9.12$ (Supp. 1966), for the Comptroller of the Currency's regulation with respect to retention by a national bank of its own shares. See generally Prochnow, Conflict of Interest and the Corporate Trustee, 22 Bus. LAw. 929, 931 (1967).
} 
wise worthy of retention, and of course the trustee must deal with the asset only in the interest of the beneficiaries. Under existing law, implied authorization to self-deal in this manner may be found under appropriate circumstances, but it is obvious that the retention of an asset in which the trustee is interested may be more easily rationalized and defended under the Act, however flexible the concept of the "implied power" may be.

It is not clear that this liberalization of self-dealing is justified. If the Chase Manhattan Bank is selected as trustee and one of many holdings transferred to it is a block of its stock, why should the trustee be permitted to retain the shares, absent express authorization to do so in the trust instrument? An exchange for shares of a comparable major bank would seem to be in the best interests of sound fiduciary administration. Under existing law, it is possible to conclude that retention is impliedly authorized, but there does not seem to be any compelling reason to make retention more easily defensible.

Retention may well be justified where the shares of a closely-held small town bank are transferred to it in trust, or where an individual trustee has an interest in a closely-held corporation, shares of which have been transferred in trust. If uniform legislation is to condone retention of assets in which the trustee is interested, then it is suggested that the provision be more narrowly drawn than the relevant provision of the Act.

Under the Act, if the asset is economically sound, then it seems that the standards of prudence and fiduciary loyalty pose no obstacle to retention. But it seems that retention should not be allowed unless the settlor intended it or there is a compelling economic purpose to justify it. This broad self-dealing provision does not appear to serve the interests of sound fiduciary administration.

\section{Deposit of Trust Funds in Account with Trustee Bank}

Section 3(c)(6) of the Act authorizes another form of self-dealing, the deposit of trust funds in an account maintained with the fiduciary bank. The limits upon this self-dealing are the requirements of management prudence and fiduciary loyalty. But the standards of prudence and loyalty are gossamer stuff where the duration of the deposit and the needs of trust liquidity are concerned. It seems that the law should discourage the trustee from this sort of conflict of interest, although there is a good deal of existing legislation permitting it. ${ }^{24}$

Is there any serious practical problem in requiring that deposits of trust funds be made with another bank? If deposits in the bank fiduciary's banking department were improper, it goes without saying that bank fiduciaries could, if they were so inclined, cooperate with one another by exchanging fiduciary deposits, thereby in-

${ }^{24}$ E.g., Conn. Gen. Stat. AnN. \$36-82 (1960); IND. Ans. Stat. $\$$ 18-1209 (1964); Mass. Gen. Laws ANN. ch. I72, $\$ 76$ (Supp. I966); Mich. STAT. ANN. $\$ \$ 23.763,23.1054$ (I957). Sce also 12 C.F.R. 9.Io (Supp. I966), for the Comptroller of the Currency's regulation with respect to national banks. See generally Prochnow, supra note 23, at 934 . 
directly achieving what could not be done directly, but this does not seem to be justification for relaxing this self-dealing restriction. The law certainly should not make it any easier for the fiduciary to serve his interests instead of the beneficiaries', unless there is some advantage to the trust which outweighs the risk of abuse. This does not seem to be the case here.

The danger of loss of deposits through bank insolvency has become remote, but tight money conditions are very much with us from time to time. In these circumstances banks value their deposits dearly; the conflict of interest can be very real. This type of self-dealing does not seem to be worthy of uniform legislative approval.

\section{Trustee Compensation}

Section $3(c)(20)$ allows the trustee to set his own compensation, subject of course to his responsibility as a fiduciary. Customarily trustee compensation is established by statute, or by application to the court, if not provided for in the trust instrument. What reason can there be for placing the burden upon the beneficiary to challenge the reasonableness of the trustee's compensation, except the convenience and advantage of the trustee? This is about as flagrantly unjustifiable a form of selfdealing as one could suggest. The Act seems to treat the payment of the trustee's compensation as just another disbursement in the management of the trust. This is rather disingenuous.

There are a couple of unusual aspects to this clause. The chairman of the committee which drafted the Act has stated that the provision is not intended to supersede any existing statutory provision establishing the rate of trustee compensation or providing a procedure for determining compensation; ${ }^{25}$ there does not appear, however, to be any basis in the language of the clause to support this restrictive interpretation. If a court were so to interpret the section, then it would be meaningful in only a limited number of jurisdictions, but it seems to be unjustifiable under any circumstances.

It is also curious that in the section 5 (b) enumeration of self-dealing practices which do not require judicial authorization, the fee setting provided for in section $3(\mathrm{c})(20)$ is not included. This literally means that section 5 (b) requires that the trustee obtain judicial approval of his compensation. But if this is so, then what is the point of including the trustee's compensation within the trustee's powers under section 3 (c) (20)? 'The matter is most unclear.

B. Employment of Specialists: Delegation, Self-Dealing, and Exculpation

Section 3 (c) (24) of the Act is a very broad provision whose terms combine elements of authorization of delegation, authorization of self-dealing, and fiduciary

\footnotetext{
${ }^{25}$ Horowiz, supra note 4 , at 23 n.r27. This interpretation means that if a statute provides for a specific scale of compensation, or if a statute provides for a maximum fee within which the court determines compensation, or if a statute provides only for court determination of the trustee's fee, then this section of the Act is of no effect. But if the court determination of the fee is a common law rule only, then this section supersedes the rule. This result would appear to be somewhat questionable.
} 
exculpation. The trustee is empowered to employ-presumably this means pay a fee to-such specialists as lawyers, accountants, and investment advisors, including specialists who are "associated" with the trustee, to rely upon the advice of such specialists without responsibility to consider its adequacy or quality, and generally to delegate any fiduciary function to another person, whether or not the function is discretionary. It should be repeated that the trustee always has a duty of prudence in management and the duty to act solely in the interests of the beneficiaries, however difficult those criteria may be to interpret and apply in the context of such a broad grant of powers to deal with oneself and to pay others to perform trust functions.

An examination of the significance of these provisions as applied to the situation of the bank fiduciary is appropriate. Does this section mean that a bank acting as trustee can pay a fee to an investment advisor and rely absolutely upon his advice? If the bank acts with proper care in its selection of the investment advisor, and if the bank needs such advice, then it seems that there is no violation of the duty of prudent management if the objective prudent man standard is employed; men of ordinary judgment use investment advisors, and may well rely completely upon their advice. There may, however, be some problem if the standard of prudence takes into account the special skill possessed or represented to be possessed by the fiduciary bank, but, as noted above, the Act leaves the application of any such higher standard in serious doubt. Assuming one applies the higher standard, the questions then are these: Does a person of extraordinary investment or property management skill employ investment advisors? If so, does he accept their recommendations without examining and assessing the conclusions himself? It is not clear where the Act leaves the matter. The authors of the Act certainly are aware that trust business is largely handled by professionals, and must have intended that the provisions of this section be utilized by banks.

The question remains why a professional fiduciary, in a time when trusts are used for the purpose of obtaining the benefits of investment skill and flexibility, can spend trust assets to get investment advice and, to make matters worse, accept such advice without any obligation to assess its worth. ${ }^{26}$ It seems that if the professional fiduciary feels unsure of its investment competence it should go out and hire people

\footnotetext{
${ }^{20}$ It is generally recognized that a trustee cannot delegate the power to sclect investments. Washington Loan \& Trust Co. v. Colby, 7 I App. D.C. 236, 108 F.2d 743 (D.C. Cir. 1939); Winthrop v. Attorney General, 128 Mass. 258 (1880); Tavenner v. Baughman, 129 W.Va. 783, 41 S.E.2d 703 (1947); RestATEMENT (SECOND) OF TRUSTS \$I7I (I959); 2 A. Scotr, supra note I, \$ 171.2.

There is the related question of whether the trustee can properly employ investment counscl at the expense of the trust, without delegating the selection of investments to the investment counsel. The case law is very limited and inconclusive. Professor Scott states that it seems to depend on whether the trustee would be expected to have the necessary skill in the investment field, "as in the case of a corporation or individual holding itself or himself out as possessing the necessary amount of skill." 2 A. ScorT, supre note I, $\$ 188.3$, at I 402 .

It is also generally accepted that the trustee has a duty to oversee the conduct of parties to whom the trustec has properly delegated a particular trust function. McClure v. Middletown Trust Co., 95 Conn. 148, I 10 A. 838 (1920); Estate of Webb, I65 Pa. 330, 30 A. 827 (1895); 2 A. ScorT, supro note $I, \$ 225 . I$.
} 
for its staff who possess such competence, or pay for consultant services out of its own funds; and it seems that under any and all circumstances it should be liable for investment action which falls below the fiduciary standard as adjusted for skills actually possessed or impliedly or expressly represented to be possessed.

The Act goes even one step further and permits self-dealing in the selection of the investment advisor; the word "associated" has something less than a precise meaning, but it must include certain forms of self-dealing. It seems that the section would permit the payment of fees to an investment advisor who was also an employee economist with the bank fiduciary, or to an investment advisory firm managed or controlled by a director of the fiduciary bank. Why cannot these advisors furnish their advice when they are wearing their bank hats? To justify these provisions by speaking of prudence and loyalty is to gloss over the issue; specific legislative powers are not easily checked by means of generalized standards of competence and honor. This type of legislative provision shifts the burden to the beneficiary to prove misconduct where the opportunity for it is substantial, the standards are imprecise, and the proof is difficult. Self-dealing and delegation should only be permitted when the risks and expense are outweighed by the utility to the trust; it seems that the burden is not met in this situation. ${ }^{27}$

This section authorizes the bank fiduciary to pay a fee to an accountant to keep the books and prepare the trust accounts, within the limits of prudence and loyalty. Most banks have accounting staffs of their own, and it seems that if they are not large enough to do all the bookkeeping for the trust department, the staff should be increased. When the provisions for the employment of the outside investment advisors and the employment of outside accountants are considered along with the power to accept their recommendations and actions without review, the question arises as to what the settlor who selects the bank fiduciary is getting for his money. It seems that he may have purchased only custodian services. ${ }^{28}$

To say that most banks will not abuse the opportunities presented by these provisions is, of course, no answer, nor is it any answer to say that the courts will be

\footnotetext{
37 There is substantial authority for the proposition that the fiduciary may hire himself or "associates" to perform trust functions which are properly delegable. Norris v. Bishop, 207 Ky. 62I, 269 S.W. 75 I (rg25) (attorney); In re Estate of Tuttle, 4 N.Y.2d 159, I49 N.E.2d 715 (1958) (accountant); Swank v. Reherd, I8I Va. 943, 27 S.E.2d 19I (1943) (attorney); G. Bocerr, stupra note $21, \$ 543(\mathrm{M})$. There is also a body of law which denies the fiduciary the power to do so. In re Estate of Parker, 200 Cal. 132, 25I P. 907 (1926) (executor's law firm); In re Lundberg's Will, 197 N.Y.S.2d 871 (Sur. Ct. 1960) (real estate broker); Lightner v. Boone, 221 N.C. 78, ig S.E.2d 144 (1942) (attorney); Montaquila v. Montaquila, 85 R.I. 447, r33 A.2d II9 (I957) (real estate broker).

${ }^{28}$ It has been held that a trustee can properly expend trust funds to employ an accountant if it is unreasonable under the circumstances to expect the trustee to do the accounting work. Hagedorn v. Arens, 106 N.J. Eq. 377, 150 A. 4 (Ch. 1930); In re Loeb, I9 Misc. 2d 139, 186 N.Y.S.2d 73I (Sur. Ct. 1959); Ealer Estate, I7 Pa. D. \& C.2d 67 (Orphans' Ct. 1958). On the other hand, if the trustee is capable of performing the accounting function involved, such expense is improper. Twist v. Twist, 22I Ark. 5Ir, 254 S.W.2d 687 (1953); Chemical Bank \& Trust Co. v. Reynaud, 150 Mise. 821, 270 N.Y.S. 301 (Sup. Ct. I933), aff'd mem., 239 App. Div. 904, 265 N.Y.S. 944 (I933); In re Estate of Rich, 27 Misc. $2 d$ 364, 21 I N.Y.S.2d 68 (Sur. Ct. 1960), aff'd mem., 13 App. Div. $2 d 464,2 r_{4}$ N.Y.S.2d 246 (I96I); Hahl Estate, 89 Pa. D. \& C. 380 (Orphans' Ct. 1954).
} 
inclined to construe such provisions very strictly. To assert that the standards of prudence and fiduciary loyalty are adequate safeguards is misleading. Within the context of this Act, it cannot be said that it is imprudent for a bank to retain outside investment advice, or accounting assistance, where the Act expressly recognizes only the external standard of ordinary skill and judgment and makes no reference to the subjective standard of possessed or represented extraordinary skill and judgment. Within the context of this Act, it cannot be said that it is a violation of the fiduciary duty to incur expense for investment advice or accounting assistance, if the bank in good faith and with justification considers that it needs it; if the bank needs it, there can be no breach of duty if the advice and assistance are obtained from "associates," to use the language of the Act.

This section seems to be an invitation to the bank fiduciary industry to pass on certain costs to the trust, while at the same time reducing the risk of surcharge by doing away with any responsibility for delegated functions. It is not suggested that this is the purpose of the section, but it certainly affords that opportunity. It should also be noted that the possible liability of the party to whom the trust function has been delegated for failure to perform with due care is a poor substitute for the responsibility of the prestigious trust company which has been selected as trustee in part for its presumed financial soundness as well as its special competence.

It is, of course, arguable that competition will force trustees' fees to reflect whether investment and accounting services are furnished internally or externally, and consequently the trust consumer will not be disadvantaged by the power of delegation afforded by the Act. This classical economic argument has a certain logical appeal, but it is premised upon the existence of genuine competition, full disclosure of trust administration practices prior to the creation of the trust, and a sophsticated consumer class; whether these conditions obtain in the trust industry is conjectural. Experience in many other consumer fields is not very reassuring. This writer would hazard the guess that many trust consumers are likely to be disadvantaged despite the allegedly benign hand of the marketplace.

There is the further question of the relationship of section $3(c)(24)$ to the individual trustee who is not possessed of business skills. Certainly an argument can be made for allowing delegation of certain functions in his case. It may well be that there should be different legislative rules for "amateur" trustees and professional trustees. But in any event an evaluation of the Act must be made upon the basis of its effect upon the professional trustee in view of its predominant position in the field.

Delegation to attorneys is a somewhat different matter. ${ }^{29}$ Most banks do not have

\footnotetext{
${ }^{20}$ There is no question that a trustee may properly employ an attorney with respect to legal questions which are beyond the competence of the layman, and delegate such duties to him as a layman would in connection with the management of his property. Estate of Barbikas, I71 Cal. App. 2d 452, 341 P.2d 32 (I959); Hanscom v. Malden \& Melrose Gas Light Co., 234 Mass. 374, 125 N.E. 626 (1920); In re Estate of Wharton, 47 N.J. Super. 42, 135 A.2d I87 (App. Div. 1957); G. BocERT, stipra note 21, $\$ 556$;
} 
house counsel staffs. Usually the trust officer is not as qualified to judge the soundness of the attorney's advice or action as he is to evaluate the advice or action of the investment advisor. Most settlors probably do not consider that in appointing a bank fiduciary they are buying legal services which may be required in the course of the administration of the trust; on the other hand the settlor probably considers that he is buying necessary accounting and investment services. However, the power to self-deal with lawyers who are, let us say, directors of the fiduciary bank, is probably inadvisable. There is usually no difficulty in finding competent lawyers who are "unassociated" to handle trust matters. Certainly in many areas the banking industry and elements of the legal community have a close relationship, but there is no point in enacting uniform legislation which condones less than arm's length dealing.

The last clause of the section broadly authorizing the delegation of any act of fiduciary administration, whether or not discretionary, probably is intended to cover individual trustee illness and absence from the country and the like. ${ }^{30}$ But it is broad enough to cover anything including delegation of discretionary distributions of income and principal. Under this clause there can also be broad delegation to a co-trustee. Once again, the standards of ordinary skill and judgment and fiduciary loyalty are supposed to be the limits of the power. It is also provided in section 4 of the Act that the trustee cannot transfer his office or the entire administration of the trust to a co-trustee or other person-now there is an objective limit! Just what this open-ended provision for delegation really entitles the trustee to do would have to await judicial construction.

\section{IV}

\section{Miscellaneous Provisions}

\section{A. Securities Need Not Be "Earmarked" As Held in Trust}

Section 3(c)(r6) of the Act empowers the trustee to hold securities in the name of a nominee or in other form which does not disclose the fact that the security is held in trust, in order that title may be transferable without difficulty. The common law view has been that the trustee must "earmark" trust assets as such, in order to protect against the possibility of confusion of trust property and individual property of the trustee and the confusion of the assets of different trusts, and to protect against the manipulation by the trustee of trust assets and individual assets in the event of fluctuating asset values. ${ }^{31}$ It has also been the common law view that one who

2 A. Scorr, supra note I, $\$ \$ I 7 I .2,188.3$. There is legislation in some states expressly recognizing the need of a fiduciary to retain legal counsel in connection with the administration of a trust. E.g., AzA. CODE tit. 58, \$5 (I958); Kan. GEN. Stat. Ann. §59-I7I7 (1949); Mich. StAT. AnN. \$27.3178(285) (1962). The trustee who employs or delegates to an attorney must, however, oversee the actions of the attorney within the limits of his competence. McClure v. Middletown Trust Co., 95 Conn. I48, r1o A. 838 (1920).

${ }^{30}$ See Horowitz, supra note 4 , at 24.

${ }^{32}$ See 2 A. ScoTr, supra note $1, \$ \S$ I79, I79.I, .2, .3. 
knowingly purchased a trust asset from a trustee or participated in the transaction was bound to make diligent inquiry as to the trust terms and any violation thereof. ${ }^{32}$ As applied to securities which were regularly traded, the requirement of earmarking made sales by a trustee extremely cumbersome. As a consequence, statutes were enacted in a number of jurisdictions authorizing corporate trustees to hold securities in other than the fiduciary name. ${ }^{33}$ The advantages of commerce in such property were considered to outweigh the dangers of the absence of earmarking.

There have also been statutes which protect the purchaser from the trustee, and those participating in the transaction, who know that trust property is being transferred but have no knowledge of any breach of trust terms; ${ }^{34}$ most recently, sections 8-304 and 8-403 of the Uniform Commercial Code protect the good faith purchaser of securities held in trust and third parties involved in the transaction.

While section 3(c)(r6) empowers the trustee to hold securities in other than the name of the trustee in order to facilitate transfers, section 7 of the Act provides that parties who deal with the trustee may safely assume that the trustee is acting within his powers. So it seems that within the terms of the Act itself the fact of earmarking of trust property does not interfere with commerce in securities. Since the purpose of not earmarking securities is no longer relevant, it seems that the traditional rule requiring earmarking should be retained. Sound fiduciary administration would require earmarking unless there is a compelling reason for doing away with it. ${ }^{35}$

This writer, however, has been advised that nominee registration makes life simpler administratively at the bank. In addition, under the rules of the New York Stock Exchange, a certificate in the name of a fiduciary is not deemed to be good delivery. ${ }^{36}$ It may be that the exchange should change its rule, but until it does it seems that nominee registration is called for. The exchange rule does not seem to be necessary any longer, but it may well serve the administrative convenience of banks and brokers.

\section{B. Duty to Retain Tax Advantages}

Section 3 (b) prohibits a trustee from exercising his broad powers under the Act in such a way as to deprive the trust or donor of a "tax exemption, deduction, or credit," or "impose a tax upon a donor or other person as owner of any portion of the trust." The taxes referred to include any federal, state, or local income, gift, estate, or inheritance tax.

\footnotetext{
${ }^{32}$ Restatement (Second) of Trusts $\$ \S 296,297,325,326$ (r959); 3 A. Scort, supro note $x$, $\$ \S 296,297,325,326$; Fratcher, supra note I, at 645-46.

${ }^{33}$ E.g., ConN. Gen. Stat. ANN. $\$ 36-81$ (I960); DeL. CODE ANN. tit. 5, \$915 (1953); INd. ANN. Stat. § 18-1213 (1964); Kan. Gen. Stat. ANn. \$9-r607 (1964); Mass. Gen. Laws ANn. ch. 167, §54 (1959).

34 Uniform Fiduciaries Act, which has been adopted in more than twenty states; Uniform Simplification of Fiduciary Security Transfers Act, which has been adopted in more than thirty-five states. Sce also Fratcher, supra note 1 , at 647-49.

${ }^{35}$ See Fratcher, supra note $x$, at $66_{3}$

${ }^{36}$ NYSE Rule 20I, 2 CCH NYSE Guide para. 2201.
} 
The chairman of the committee that drafted the Act has noted the relationship of this clause to the exempt charitable trust under section 50I(c) (3) of the Internal Revenue Code of 1954 , the grantor trust under Code sections $67 \mathrm{I}$ through 678 , and the marital deduction trust under Code section 2056. ${ }^{37}$ He points out that a trustee of an exempt charitable trust who engaged in a prohibited transaction as defined in section 503 of the Code which would cause the loss of the exempt status would be in violation of the Act; on the other hand, the trustee of an exempt trust who invests so as to produce unrelated business income as defined in Code sections 5II-I5, is not in violation of the Act since he has not destroyed the exempt status of the trust, but merely subjected it to some tax liability. This appears to be a rather fine reading of section $3(\mathrm{~b})$. He also points out that the Act denies to the trustee the power to do any of the things described in Code section 675 , and states, by way of example, that section 3 (b) would not prohibit a trustee from disposing of tax-exempt bonds and reinvesting in taxable assets.

It seems that the breadth of the language of the section and the variety of taxes to which it relates would cause considerable concern to a trustee. ${ }^{38}$

\section{Other Departures from Historical Restrictions}

The Act has a number of specific provisions which expand trustee powers in a manner which would free fiduciary administration from certain limitations of its restrtictive historical legacy. Section $3(c)(3)$ broadly empowers the trustee to operate a business, subject of course to the limitation of the prudence of such action with respect to the preservation of principal as well as the production of income. Section $3(c)(7)$ frees the trustee to acquire or dispose of an asset on credit, and to encumber a trust asset for a valid trust purpose. Sections 3 (c)(8), (9), (10), and (II) free the trustee's hand in the management and improvement of real property held in trust. Section 3 (c) (I2) empowers the trustee to give options to purchase trust property. Section $3(\mathrm{c})(\mathrm{I} 3)$ gives the trustee broad power to vote stock by proxy.

Section $3(c)(x 8)$ empowers the trustee to borrow money for the trust. Section 3 (c) (22) permits the trustee to make distribution to a relative of a beneficiary who is under disability, or to the beneficiary himself, in the absence of a legal representative. Section 6 allows a majority of the trustees to act for the trust if there are three or more trustees, with exculpation provided for any dissenting trustee. As previously indicated, section 7 contains provisions that serve to protect the third party who deals with the trustee; broad third party protection is particularly neces-

\footnotetext{
${ }^{37}$ Horowitz, supra note 4 , at $\mathrm{I}_{3}-\mathrm{I} 6$.

${ }^{38}$ Rev. Rul. I44, I965-I Cus. Bull. 442, ruled invalid as contrary to public policy, as clause in a trust instrument providing that a power in a trustee to divert principal to noncharitable "income" beneficiaries was to be of no effect if the consequence of such power was to make a charitable remainder not deductible for federal gift or income tax purposes. Horowitz, supra note 4 , at $I 6 \mathrm{n} .86$, distinguishes such a clause from section 3 (b) of the Act on the ground that the latter is a statutory prohibition.
} 
sary if the powers of the trustee are to be liberalized to enable him to do whatever is prudent in the management of the trust.

Section 5(a) recognizes the existing power of the court to authorize deviation from administrative restrictions upon the trustee imposed by the trust instrument or the Act. The wording of this section is such that it could be construed to liberalize the power of the court to authorize deviation-that is, to authorize it when it would be simply advantageous to the trust to do so, rather than only in the event of circumstances which threaten to impair the accomplishment of the purposes of the trust. The liberalization of the doctrine of deviation, however, does not seem to have been the intent of those who drafted the Act. ${ }^{39}$

\section{$\mathrm{V}$}

\section{Reflections and Conclusions}

The basic concept of the Act, namely the establishment of a flexible, commonsense standard to determine the scope of trustees' powers, is certainly sound. What is proposed approaches in principle the commendable idea of powers existing by virtue of the office or function. But unfortunately it is here at the very foundation that a flaw appears.

The Act establishes as its fundamental standard the conduct of the man of ordinary prudence and judgment. But modern fiduciary responsibility is largely in the hands of the trust companies, the institutional experts, who usually possess, and necessarily represent that they possess, special competence in the management of property. The better thinking in the fiduciary field supports the proposition that the standard of care and skill should be as extensive as the level of competence of the trustee, in fact or represented. But the Act does not reflect this higher standard. The Act deals with powers, but obviously the powers of the trustee are, to a considerable degree, the function of his duties, and cannot fall below the level of his duties. If the failure to include this higher standard in the definition of the fundamental principle of trustee power in the Act was a drafting oversight, then it should be corrected; if the omission was deliberate, then the effect of the Act would seem to be the unhappy one of the downgrading of fiduciary responsibility.

Since this issue permeates the entire Act, it should be discussed before the Act is given further consideration by legislatures. If the Act is widely adopted without change in this regard, it will be viewed by many as a regressive step.

The self-dealing aspects of the Act are troublesome. Retention of assets in which the trustee is personally interested, deposits of trust funds with the trustee bank, trustee determination of its own compensation, and trustee delegation to "associates," are all allowed without court authorization. Prudence and loyalty are set up as the bulwarks against abuse. Why were self-dealing purchases and sales omitted? Why

\footnotetext{
${ }^{80}$ Horowitz, supra note 4 , at 25-26.
} 
are not the duties of prudence and loyalty sufficient protection against abuse there as well? Self-dealing conflicts with the fiduciary idea, and it should only be permitted where advantage to the trust outweighs the risk involved. If there is a place in uniform legislation for self-dealing without judicial or settlor authorization, it should be narrowly and tightly defined. This has not been done in the Act.

The breadth of the delegation authority in the Act is remarkable in light of the predominant position of the institutional fiduciary. If the judicial opposition to delegation by the trustee was originally founded on settlor confidence in the designated individual, today opposition to delegation can be rationalized in terms of the settlor expectation when he chooses a many-faceted financial-fiduciary institution as his trustee. There may well be matters and situations which call for delegation of the fiduciary function, particularly with respect to the individual trustee, but uniform legislation should attempt to define them with greater precision than merely the limits of prudence and loyalty.

The Act provides that all its terms can be negated by the settlor in the trust instrument. Such negation is, of course, subject to the equity power to order or authorize deviation when the the settlor's restraints threaten the broader purposes of the trust. But this is a remedy reserved for the extraordinary situation. The issue that this provision of the Act raises is that of dead-hand control. It is accepted in trust law that the settlor is free to give his property on his own administrative terms. The Act purports to provide the trustee great freedom of action, but it leaves room for the settlor to say "no" and thereby impose his will upon the living long after his death. The question is whether settlor control over presumably salutary statutory powers is sound policy. It can be argued that settlor control over the management of trust property should be strictly limited. A reappraisal of dead-hand control over wealth is long overdue. Fiduciary powers is only one aspect of a larger problem. ${ }^{40}$

In this connection, section 5(a) of the Act confirms the doctrine of administrative deviation, and apparently there was no intention to expand it although the language of the section could be construed to do so. ${ }^{41}$ A strong argument can be made for the proposition that the court should be empowered to authorize deviation from restrictive administrative terms in the trust instrument when it would be to the advantage of the trust to do so. It may be advisable to restate the clause to effect clearly a liberalization of the law in this regard.

Should legislatures enact the Uniform Trustees' Powers Act? This writer thinks not, at least in its present form. This is not to say that it is not a thoughtful product with many valuable features. But on balance, it does not seem to be a truly progressive step in the development of trust law.

\footnotetext{
${ }^{10}$ See L. Simes, Public Policy and the Dead Hand (1955); W. Leach, Property Law Indicted 3 I49 (1967); Haskell, Justifying the Principle of Distributive Deviation in the Lavv of Trusts, I 8 Hastings L.J. $267(1967)$.

"2 See Horowitz, supra note 4, at 25-26.
} 


\section{APPENDIX \\ TEXT OF THE UNIFORM TRUSTEES' POWERS ACT}

\section{$\S$ I. [Definitions]}

As used in this Act:

(I) "trust" means an express trust created by a trust instrument, including a will, whereby a trustee has the duty to administer a trust asset for the benefit of a named or otherwise described income or principal beneficiary, or both; "trust" does not include a resulting or constructive trust, a business trust which provides for certificates to be issued to the beneficiary, an investment trust, a voting trust, a security instrument, a trust created by the judgment or decree of a court, a liquidation trust, or a trust for the primary purpose of paying dividends, interest, interest coupons, salaries, wages, pensions or profits, or employee benefiits of any kind, an instrument wherein a person is nominee or escrowee for another, a trust created in deposits in any financial institution, or other trust the nature of which does not admit of general trust administration;

(2) "trustee" means an original, added, or successor trustee;

(3) "prudent man" means a trustee whose exercise of trust powers is reasonable and equitable in view of the interests of income or principal beneficiaries, or both, and in view of the manner in which men of ordinary prudence, diligence, discretion, and judgment would act in the management of their own affairs.

\section{Commissioners' Note}

What is "reasonable and equitable" in the exercise of trust powers will be determined as of the time of exercise.

\section{$\S 2$. [Powers of Trustee Conferred by Trust or by Law]}

(a) The trustee has all powers conferred upon him by the provisions of this Act unless limited in the trust instrument [and except as is otherwise provided in

(b)An instrument which is not a trust under section $I(x)$ may incorporate any part of this Act by reference.

\section{\$. [Powers of Trustees Conferred by this Act]}

(a) From time of creation of the trust until final distribution of the assets of the trust, a trustee has the power to perform, without court authorization, every act which a prudent man would perform for the purposes of the trust including but not limited to the powers specified in subsection (c).

(b) In the exercise of his powers including the powers granted by this Act, a trustee has a duty to act with due regard to his obligation as a fiduciary, including a duty not to exercise any power under this Act in such a way as to deprive the trust of an otherwise available tax exemption, deduction, or credit for tax purposes or deprive a donor of a trust asset of a tax exemption, deduction, or credit or operate to impose a tax upon a donor or other person as owner of any portion of the trust. "Tax" includes, but is not limited to, any federal, state, or local income, gift, estate, or inheritance tax.

(c) A trustee has the power, subject to subsections (a) and (b):

(I) to collect, hold, and retain trust assets received from a trustor until, in the judgment of the trustee, disposiiton of the assets should be made; and the assets may 
be retained even though they include an asset in which the trustee is personally interested;

(2) to receive additions to the assets of the trust

(3) to continue or participate in the operation of any business or other enterprise, and to effect incorporation, dissolution, or other change in the form of the organization of the business or enterprise;

(4) to acquire an undivided interest in a trust asset in which the trustee, in any trust capacity, holds an undivided interest;

(5) to invest and reinvest trust assets in accordance with the provisions of the trust or as provided by law;

(6) to deposit trust funds in a bank, including a bank operated by the trustee;

(7) to acquire or dispose of an asset, for cash or on credit, at public or private sale; and to manage, develop, improve, exchange, partition, change the character of, or abandon a trust asset or any interest therein; and to encumber, mortgage, or pledge a trust asset for a term within or extending beyond the term of the trust, in connection with the exercise of any power vested in the trustee;

(8) to make ordinary or extraordinary repairs or alterations in buildings or other structures, to demolish any improvements, to raze existing or erect new party walls or buildings;

(9) to subdivide, develop, or dedicate land to public use; or to make or obtain the vacation of plats and adjust boundaries; or to adjust differences in valuation on exchange or partition by giving or receiving consideration; or to dedicate easements to public use without consideration;

(ro) to enter for any purpose into a lease as lessor or lessee with or without option to purchase or renew for a term within or extending beyond the term of the trust;

(II) to enter into a lease or arrangement for exploration and removal of minerals or other natural resources or enter into a pooling or unitization agreement;

(x2) to grant an option involving disposition of a trust asset, or to take an option for the acquisition of any asset;

(13) to vote a security, in person or by general or limited proxy;

(I4) to pay calls, assessments, and any other sums chargeable or accruing against or on account of securities;

(I5) to sell or exercise stock subscription or conversion rights; to consent, directly or through a committee or other agent, to the reorganization, consolidation, merger, dissolution, or liquidation of a corporation or other business enterprise;

(x6) to hold a security in the name of a nominee or in other form without disclosure of the trust, so that title to the security may pass by delivery, but the trustee is liable for any act of the nominee in connection with the stock so held;

(I7) to insure the assets of the trust against damage or loss, and the trustee against liability with respect to third persons;

(I8) to borrow money to be repaid from trust assets or otherwise; to advance money for the protection of the trust, and for all expenses, losses, and liabilities sustained in the administration of the trust or because of the holding or ownership of any trust assets, for which advances with any interest the trustee has a lien on the trust assets as against the beneficiary;

(I9) to pay or contest any claim; to settle a claim by or against the trust by com- 
promise, arbitration, or otherwise; and to release, in whole or in part, any claim belonging to the trust to the extent that the claim is uncollectible;

(20) to pay taxes, assessments, compensation of the trustee, and other expenses incurred in the collection, care, administration, and protection of the trust;

(2I) to allocate items of income or expense to either trust income or principal, as provided by law, including creation of reserves out of income for depreciation, obsolescence, or amortization, or for depletion in mineral or timber properties;

(22) to pay any sum distributable to a beneficiary under legal disability, without liability to the trustee, by paying the sum to the beneficiary or by paying the sum for the use of the beneficiary either to a legal representative appointed by the court, or if none, to a relative;

(23) to effect distribution of property and money in divided or undivided interests and to adjust resulting differences in valuation;

(24) to employ persons, including attorneys, auditors, investment advisors, or agents, even if they are associated with the trustee, to advise or assist the trustec in the performance of his administrative duties; to act without independent investigation upon their recommendations; and instead of acting personally, to employ one or more agents to perform any act of administration, whether or not discretionary;

(25) to prosecute or defend actions, claims, or proceedings for the protection of trust assets and of the trustee in the performance of his duties;

(26) to execute and deliver all instruments which will accomplish or facilitate the exercise of the powers vested in the trustee.

§. [Trustee's Office not Transferable]

The trustee shall not transfer his office to another or delegate the entire administration of the trust to a cotrustee or another.

$\S 5$. [Power of Court to Permit Deviation or to Approve Transactions Involving Conflict of Interest]

(a) This Act does not affect the power of a court of competent jurisdiction for cause shown and upon petition of the trustee or affected beneficiary and upon appropriate notice to the affected parties to relieve a trustee from any restrictions on his power that would otherwise be placed upon him by the trust or by this Act.

(b) If the duty of the trustee and his individual interest or his interest as trustee of another trust, conflict in the exercise of a trust power, the power may be exercised only by court authorization (except as provided in sections 3(c) (r), (4), (6), (r8), and (24)) upon petition of the trustee. Under this section, personal profit or advantage to an affiliated or subsidiary company or association is personal profit to any corporate trustee.

\section{$\S 6$. [Powers Exercisable by Joint Trustees-Liability]}

(a) Any power vested in 3 or more trustees may be exercised by a majority, but a trustee who has not joined in exercising a power is not liable to the beneficiaries or to others for the consequences of the exercise; and a dissenting trustee is not liable for the consequences of an act in which he joins at the direction of the majority of the trustees, if he expressed his dissent in writing to any of his cotrustees at or before the time of the joinder.

(b) If 2 or more trustees are appointed to perform a trust, and if any of them is unable or refuses to accept the appointment, or, having accepted, ceases to be a trustee, the 
surviving or remaining trustees shall perform the trust and succeed to all the powers, duties, and discretionary authority given to the trustees jointly.

(c) This section does not excuse a cotrustee from liability for failure either to participate in the administration of the trust or to attempt to prevent a breach of trust.

\section{§. [Third Persons Protected in Dealing with Trustee]}

With respect to a third person dealing with a trustee or assisting a trustee in the conduct of a transaction, the existence of trust power and their proper exercise by the trustee may be assumed without inquiry. The third person is not bound to inquire whether the trustee has power to act or is properly exercising the power; and a third person, without actual knowledge that the trustee is exceeding his powers or improperly exercising them, is fully protected in dealing with the trustee as if the trustee possessed and properly exercised the powers he purports to exercise. A third person is not bound to assure the proper application of trust assets paid or delivered to the trustee.

\section{\$. [Application of Act]}

Except as specifically provided in the trust, the provisions of this Act apply to any trust established [before or] after the effective date of this Act [and to any trust asset acquired by the trustee [before or] after the effective date of this Act].

\section{Commissioners' Note}

If the bracketed provisions are included in the Act as adopted, the provisions of this section will not affect the validity of any act of the trustee performed prior to its enactment.

\section{§. [Uniformity of Interpretation]}

This Act shall be construed to effectuate its general purpose to make uniform the law of those states which enact it.

\section{§ ro. [Short Title]}

This Act may be cited as the "Uniform Trustees' Powers Act."

\section{§Ix. [Severability]}

If any provision of this Act or the application thereof to any person or circumstance is held invalid, the invalidity does not affect other provisions or applications of the Act which can be given effect without the invalid provision or application, and to this end the provisions of this Act are severable.

$\S$ I2. [Repealed]

The following acts are repealed:

(I)

(3)

§ 13. [Time of Taking Effect]

This Act takes effect 
